\title{
Pengaruh Aerobic Exercise Untuk Meningkatkan Upper Body Strength Pada Calon Jamaah Umrah
}

\author{
Agustiyawan $^{1)}$, Dzakyah Amelya ${ }^{2)}$ \\ ${ }^{1,2)}$ Program Studi Fisioterapi Program Diploma Tiga, Fakultas Ilmu Kesehatan, UPN Veteran Jakarta \\ Kampus I J1. RS Fatmawati No.1 Pondok Labu, Jakarta Selatan, Kodepos 12450 \\ Kampus II Jl. Raya Limo, Kecamatan Limo, Kota Depok, Kodepos 16515 \\ Telp. 021-7532884 \\ Email : ${ }^{1)}$ agustiyawan@upnvj.ac.id , ${ }^{2)}$ dzakyahamelya@gmail.com
}

\begin{abstract}
Background: The majority of Indonesian pilgrims are carried out by adults and elderly. Increasing a person's age will cause a decrease in the function of body cells that can result in decreased physical fitness one of which is muscle strength. Upper body muscle strength can affect functional activity. To achieve good muscular strength, aerobic exercise is needed. This study aims to determine the effect of aerobic exercise to increase upper body strength in prospective Umrah pilgrims. Research Method: uses a randomized one group pre-post test method, which is to find the difference between before and after given aerobic exercise for 3 weeks and measuring upper body strength using a curl up test. Sampling was obtained as many as 20 people from prospective pilgrims to KBIH Al-Ikhlas taken randomly according to inclusion and exclusion criteria. Data were processed and analyzed with the application of SPSS 24 software. Results: Analysis of the Wilcoxon test with the results of $p=0,000$ which showed $p<0.05$ can be stated the influence of aerobic exercise on upper body strength in prospective Umrah pilgrims.
\end{abstract}

Keywords: Aerobic Exercise, Upper Body Strength, Elderly Umrah Candidates

\begin{abstract}
ABSTRAK
Latar Belakang: Jamaah umrah Indonesia mayoritas dilakukan oleh usia dewasa dan lanjut usia. Bertambahnya usia seseorang akan menyebabkan penurunan fungsi sel-sel tubuh yang dapat mengakibatkan penurunan kebugaran fisik salah satunya kekuatan otot. Kekuatan otot tubuh bagian atas dapat berpengaruh terhadap aktivitas fungsional. Untuk mencapai kekuatan otot yang baik maka diperlukan latihan berupa aerobic exercise. Penelitian ini bertujuan untuk mengetahui pengaruh aerobic exercise untuk meningkatkan upper body strength pada calon jamaah umrah. Metode penelitian ini menggunakan metode randomized one grup pre-post test yaitu untuk mencari perbedaan antara sebelum dan sesudah diberikan latihan aerobik selama 3 minggu dan pengukuran upper body strength menggunakan curl up test. Pengambilan sampel didapatkan sebanyak 20 orang dari calon jamaah umrah KBIH Al-Ikhlas yang diambil secara acak sesuai dengan kriteria inklusi dan eksklusi. Data diolah dan dianalisa dengan aplikasi software SPSS 24. Hasil: Analisa uji Wilcoxon dengan hasil $\mathrm{p}=0,000$ yang menunjukkan $\mathrm{p}<0,05$ dapat dinyatakan adanya pengaruh aerobic exercise terhadap upper body strength pada calon jamaah umrah.
\end{abstract}

Kata Kunci: Aerobic Exercise, Upper Body Strength, Calon Jamaah Umrah Lansia 


\section{PENDAHULUAN}

Ibadah umrah ialah rangkaian kegiatan perjalanan ibadah umrah di luar musim haji yang dilaksanakan oleh setiap orang beragama muslim. Ibadah umrah dalam 3 tahun terakhir mengalami peningkatan yang signifikan, pada tahun 2018 sebanyak \pm 1 juta masyarakat muslim Indonesia menjalankan ibadah umrah (Direktur Haji dan Umrah, 2019). Jamaah umrah Indonesia mayoritas dilakukan oleh usia dewasa dan lanjut usia serta berjenis kelamin perempuan sebanyak 23.311 jamaah $^{(1)}$.

Proses penuaan terjadi setelah umur 50 tahun, hal itu berkaitan dengan perubahan fungsional tubuh manusia yaitu hilangnya massa tubuh sebesar 1-2\% dan penurunan kekuatan otot $1,5-5 \%$ setiap tahunnya ${ }^{(2)}$. Bertambahnya usia seseorang akan menyebabkan penurunan fungsi sel-sel tubuh yang dapat mengakibatkan penurunan kebugaran fisik salah satunya kekuatan otot ${ }^{(3)}$. Penurunan kekuatan otot pada usia > 40 tahun berkisar 40,9\%. Oleh karena itu untuk mempertahankan kondisi otot tetap optimal maka diperlukan latihan kebugaran fisik dan asupan nutrisi yang baik ${ }^{(4)}$.

Kebugaran fisik yang dapat dioptimalkan salah satunya upper body strength yaitu dengan meningkatkan kekuatan otot external oblique. Kekuatan otot tubuh bagian atas (upper body strength) dapat berpengaruh terhadap aktivitas kegiatan umrah yaitu, meningkatkan stabilisasi tubuh ketika terjadi desak-desakan dalam pelaksanaan ibadah umrah, mempertahankan postur tubuh dan membantu dalam aktivitas fungsional, seperti mengangkat barang, duduk, berdiri, berjalan, berlari, dan melompat ${ }^{(5)}$. Jika jamaah umrah memiliki kekuatan otot tubuh bagian atas yang baik maka akan mendukung pelaksanaan ibadah umrah. Kemampuan upper body strength dapat diukur dengan curl up test.

Tenaga kesehatan yang memahami anatomi, fisiologi, dan biomekanik dalam membantu calon jamaah umrah untuk meningkatkan upper body strength ialah fisioterapi. Fisioterapi adalah bagian penting dari sistem pelayanan kesehatan dengan memaksimalkan kualitas hidup dan potensi gerak individu, diantaranya; meningkatkan kemampuan fisik dan fungsional tubuh, mengembalikan, memelihara, dan mempromosikan fungsi fisik yang optimal, kebugaran dan kesehatan jasmani ${ }^{(6)}$.

Program latihan fisioterapi untuk meningkatkan upper body strength pada calon jamaah umrah berupa latihan kebugaran menggunakan aerobic exercise dengan jenis brisk waking exercise. Tujuan dalam penelitian ini adalah untuk mengetahui pengaruh aerobic exercise untuk meningkatkan upper body strength pada calon jamaah umrah.

\section{TINJAUAN PUSTAKA}

\subsection{Upper Body Strength}

Komponen penting untuk peningkatan kondisi fisik secara keseluruhan adalah kekuatan otot ${ }^{(7)}$. Kekuatan otot sebagai kualitas yang memungkinkan pengembangan otot dalam kontraksi yang maksimal ${ }^{(8)}$. Kekuatan otot merupakan kemampuan kelompok otot untuk mengerahkan gaya kontraktil maksimal terhadap resistensi dalam kontraksi tunggal. Dalam proses penuaan dapat mengubah pola serat otot dan akan menyebabkan perlambatan waktu kontraksi dan perlambatan kecepatan kontraksi otot. Oleh karena itu, kekuatan otot dan massa otot merupakan hal yang penting ${ }^{(9)}$.

Dalam Sebuah penelitian menyatakan bahwa faktor yang dapat mempengaruhi upper body strength ialah jenis kelamin, ukuran cross sectional otot, hubungan antara panjang dan tegangan otot pada waktu kontraksi, recruitmen motor unit, tipe kontraksi, jenis serabut otot, ketersediaan energi dan aliran darah, dan motivasi (Marunduh et al., 2015). Selain itu makanan dan asupan gizi serta aktifitas fisik yang rutin juga sangat penting dalam mempengaruhi upper body strength ${ }^{(10)}$. Kekuatan otot tubuh bagian atas (upper body strength) yaitu otot external oblique memiliki manfaat pada calon jamaah umrah yaitu, meningkatkan stabilisasi tubuh ketika terjadi desak-desakan dalam pelaksanaan ibadah umrah, mempertahankan postur tubuh dan membantu dalam aktivitas fungsional, seperti mengangkat barang, duduk, berdiri, berjalan, berlari, dan melompat ${ }^{(11)}$.

Curl up test merupakan pengukuran yang valid dan reliabilitas digunakan untuk mengukur upper body strength pada otot abdominal (otot perut) ${ }^{(12)}$. Prosedur curl up test sebagai berikut (Linda et al., 2013): Subjek berbaring dalam posisi terlentang melintasi kertas pembatas dengan jarak $8 \mathrm{~cm}$ (untuk sampel $\geq 45$ tahun), lutut ditekuk dengan sudut $90^{\circ}$ dengan kaki rata pada lantai. Test ini mengharuskan sample untuk mengangkat kepala dan bahu dengan sudut $30^{\circ}$, dengan meraih tangan ke depan hingga jari-jari sampel menyentuh kertas pembatas kedua. Tes ini dihentikan apabila sampel sudah mencapai 75 curl up 


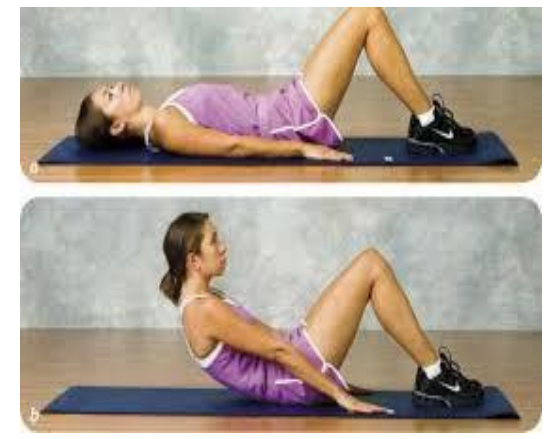

Gambar 1 Curl Up Test

\subsection{Aerobic Exercise}

Aerobic exercise merupakan aktivitas fisik yang mempunyai intensitas rendah, sedang atau tinggi yang dapat kita pertahankan selama lebih dari beberapa menit dengan tujuan meningkatkan kebugaran kardiorespirasi dan kesehatan ${ }^{(13)}$. Beberapa contoh latihan aerobik yaitu bersepeda, menari, hiking, jogging / lari jarak jauh, berenang, berjalan ${ }^{(14)}$.

Jenis aerobic exercise yang digunakan yaitu brisk walking. Dengan prosedur brisk walking exercise sebagai berikut ${ }^{(15)}$ : (1) Sampel melakukan pemanasan terlebih dahulu (2) Kemudian, berjalan dengan langkah cepat dan atur nafas panjang secara dalam (3) Angkat sedikit kepala dan dada serta pertahankan bagian perut bawah (4) Lalu, lengan siku ditekuk dengan sudut 90 diderajat (5) Tutup jari-jari tangan dengan kepalan tangan yang santai dan letakkan didekat pinggang (6) Ayunkan lengan kedepan dengan tetap menjaga tingkat tangan agar lebih rendah dari dada (7) Lutut tidak seharusnya terkunci tetapi tetap santai (8) Pada saat melangkah tubuh dalam posisi tegak dan tumit yang lebih dulu menyentuh lantai diikuti oleh telapak kaki dengan ibu jari kaki sebagai tumpuan sebelum kaki yang lain memulai langkah ke depan (9) Dilakukan dengan jarak 1,6 km selama 18-20 menit.

Dosis aerobic exercise pada penelitain ini bersifat kontinyu yaitu: Frekuensi 2x seminggu, dengan jarak 1,6 Km, waktu 18-20 menit (Istirahat : 5 menit), pengulangan $1 \mathrm{x}$, set $1 \mathrm{x}$, dan durasi $1 \mathrm{x}$.

\section{METODE PENELITIAN}

\subsection{Rancangan Penelitian}

Desain penelitian yang digunakan adalah metode randomized one grup pre-post test yaitu untuk mengetahui pengaruh upper body strength setelah diberikan aerobic exercise pada calon jamaah umrah selama 3 minggu.

\subsection{Waktu dan Tempat Penelitian}

Penelitian dilakukan di lapangan Masjid KBIH Al-Ikhlas Jakarta pada bulan Februari-Maret tahun 2020 .

\subsection{Teknik Pengambilan Sampel}

Pada penelitian didapatkan sampel berjumlah 20 orang, sampel diambil secara acak sesuai dengan kriteria inklusi dan eksklusi. Sampel yang terpilih menjadi subjek penelitian diberikan penjelasan mengenai program penelitian yang akan dilakukan. Sampel yang mengikuti program penelitian diminta untuk mengisi informed consent.

\subsection{Prosedur Intervensi}

Langkah-langkah dalam prosedur penelitian ini dibagi menjadi 6 bagian yaitu:

1. Prosedur administrasi

Pada tahap persiapan administrasi penelitian yang dilaksanakan sebagai berikut: (1) Melakukan studi keperpustakaan atau mempelajari dari buku, jurnal, internet, file, dan dari berbagai topic lain yang relevan (2) Mengurus surat-surat perizinan untuk melakukan penelitian dilokasi yang sudah ditentukan (3) Membuat rangkaian jadwal untuk pelaksanaan penelitian (4) Mempersiapkan bahan, alat ukur dan instrument yang diperlukan selama penelitian berlangsung (5) Mempersiapkan informed consent sebagai surat persetujuan untuk melakukan penelitian kepada sampel penelitian.

2. Prosedur pemilihan sampeL

Dalam penelitian ini pemilihan sampel mengacu pada karakteristik tertentu yang telah ditetapkan yaitu Kriteria Inklusi: (1) Usia 45 - 75 tahun (2) Jenis kelamin pria maupun wanita (3) Tidak memiliki penyakit degenerative grade III (4) Par-Q \& You yang layak untuk melakukan latihan (5) Tekanan darah dengan sistolik $\leq 160 \mathrm{mmHg}$ dan diastolik $\leq 100 \mathrm{mmHg}$ (6) Bersedia untuk menjadi sampel penelitian dengan menandatangani atau dengan cap jempol. Kriteria Eksklusi : (1) Sudah terbiasa melakukan latihan kebugaran yang serupa dalam waktu 3 bulan terakhir (2) Berdasarkan riwayat catatan medis, terdapat penyakit atau gangguan tulang belakang dan mengalami immobilisasi (3) Memiliki masalah cardiovaskuler dan neuromuskuler.

3. Prosedur pelaksanaan penelitian

Pada tahap pelaksanaan penelitian terdiri dari: (1) Tahap pengukuran awal, prosedur yang dilakukan meliputi memberikan penjelasan sekaligus meminta persetujuan kepada sampel mengenai rencana latihan, melakukan assessment seperti pemeriksaan vital sign, dan Par-Q \& You sesuai format yang telah disediakan, 
melakukan pengukuran curl up test sebelum intervensi, kemudian dokumentasikan hasil tes dan rekapitulasi data. (2) Tahap pelatihan dapat dilakukan di dalam ruangan atau lapangan terbuka yaitu sampel melakukan warming up (pemanasan), kemudian sampel melakukan latihan aerobic exercise, lalu melakukan cooling down (pendinginan). (3) Tahap pengukuran akhir meliputi setelah sampel melakukan latihan selama 3 minggu dengan 2 kali pertemuan, kemudian sampel melakukan pengukuran curl up test sesuai dengan format yang telah disiapkan, lalu peneliti mencatat hasil yang didapat dan didokumentasikan.

\section{HASIL DAN PEMBAHASAN}

Hasil penelitian yang telah dilakukan selama 3 minggu dengan pemberian aerobic exercise terhadap 20 sampel calon jamaah umrah didapatkan hasil penelitian sebagai berikut:

\subsection{Karakteristik Subjek Penelitian}

Karakteristik subjek penelitian berkaitan dengan umur, tinggi badan, dan berat badan. Keseluruhan data karakteristik sampel diuji dengan analisa deskriptif pada SPSS, ditunjukkan pada tabel 1 yaitu:

Tabel 1 Uji Deskriptif

\begin{tabular}{|l|c|r|r|r|r|r|}
\hline & $\mathrm{N}$ & & Min & Max & Mean & $\begin{array}{c}\text { Std. } \\
\text { Deviation }\end{array}$ \\
\hline Usia & 20 & & 45 & 72 & 53.90 & 6.973 \\
\hline BB & 20 & & 51 & 96 & 66.65 & 11.156 \\
\hline TB & 20 & & 153 & 171 & 160.80 & 5.297 \\
\hline
\end{tabular}

Deskriptif data pada tabel diatas didapatkan hasil bahwa dalam penelitian ini rerata usia sebesar $53,90 \pm 6,9$ tahun dengan nilai minimum dan maksimum masing-masing 45 tahun dan 72 tahun. Dalam karakteristik berat badan dengan rerata 66,65 \pm $11,1 \mathrm{~kg}$ dengan nilai minimum sebesar $51 \mathrm{~kg}$ dan nilai maksimum sebesar $96 \mathrm{~kg}$, dan tinggi badan dalam sampel ini dengan rerata $160,8 \pm 5,2 \mathrm{~cm}$ dengan nilai minimum $153 \mathrm{~cm}$ dan nilai maksimum $171 \mathrm{~cm}$.

\subsection{Uji Normalitas}

Uji Normalitas dalam penelitian ini menggunakan uji Saphiro Wilk test yang ditunjukkan pada tabel 2 sebagai berikut:

Tabel 2 Uji Normalitas

\begin{tabular}{|l|r|r|r|}
\hline & Statistic & df & Sig. \\
\hline StrengthU_Pre & .901 & 20 & .042 \\
\hline StrengthU_Post & .864 & 20 & .009 \\
\hline
\end{tabular}

Data hasil uji normalitas dikatakan normal jika $\mathrm{p}$ value $(\mathrm{sig})>0,05$. Dari tabel diatas didapatkan hasil bahwa uji normalitas berdistribusi tidak normal dengan hasil sebelum intervensi 0,042 dan sesudah intervensi dengan nilai 0,009 .

\subsection{Uji Homogenitas}

Analisis data untuk menguji homogenitas menggunakan levene's test, ditunjukkan pada tabel 3 berikut:

Tabel 3 Uji Homogenitas

\begin{tabular}{|c|c|c|c|}
\hline & & $\mathrm{F}$ & Sig. \\
\hline $\begin{array}{l}\text { StrengthU } \\
\text { _Pre }\end{array}$ & $\begin{array}{c}\text { Equal variances } \\
\text { assumed } \\
\text { Equal variances not } \\
\text { assumed }\end{array}$ & .150 & .703 \\
\hline $\begin{array}{l}\text { StrengthU } \\
\text { _Post }\end{array}$ & $\begin{array}{c}\text { Equal variances } \\
\text { assumed } \\
\text { Equal variances not } \\
\text { assumed }\end{array}$ & .005 & .946 \\
\hline
\end{tabular}

Data hasil uji homogenitas dikatakan homogen jika $\mathrm{p}$ value $(\mathrm{sig})>0,05$. Berdasarkan tabel diatas menunjukkan hasil bahwa data pre-post test berdistribusi homogen dengan nilai masing-masing 0,703 dan 0.946 .

\subsection{Uji Hipotesis}

Didapatkan hasil bahwa data bersifat tidak normal (non parametric) maka menggunakan uji Wilcoxon, seperti yang ditunjukkan pada tabel 4 berikut ini:

Tabel 4 Uji Hipotesis

\begin{tabular}{|l|r|}
\hline \multicolumn{2}{|c|}{ Test Statistics $^{\text {a }}$} \\
\hline & $\begin{array}{r}\text { StrengthU_Post - } \\
\text { StrengthU_Pre }\end{array}$ \\
\hline$Z$ & $-3.924^{\mathrm{b}}$ \\
\hline $\begin{array}{l}\text { Asymp. Sig. } \\
\text { (2-tailed) }\end{array}$ & .000 \\
\hline
\end{tabular}

Berdasarkan tabel diatas menunjukan hasil bahwa nilai sig (2-tailed) $<0,05$ dapat dinyatakan adanya pengaruh aerobic exercise terhadap upper body strength pada calon jamaah umrah.

\subsection{Pembahasan}

\section{Pengaruh Aerobic Exercise untuk Meningkatkan Upper Body Strength}

Pada penelitian ini calon jamaah umrah berusia antara 45-72 tahun, yang dimana sudah dikategorikan sebagai lansia. Pada lansia dapat terjadi gangguan neuromuskuler yang terkait dengan penurunan neuron motorik tulang belakang serta penurunan jumlah dan ukuran serat otot sehingga menyebabkan hilangnya 
kinerja otot yang dapat membahayakan individu. (Sbardelotto et al., 2019). Penurunan kekuatan otot merupakan faktor penting terhadap penurunan aktivitas fungsional dan terjadinya disabilitas pada lanjut usia. Pengurangan jumlah dan ukuran serabut otot tipe 2 serta proses neurogenik progresif secara perlahan akan mengakibatkan penurunan massa otot dan kekuatan otot. Olahraga menjadi salah satu cara untuk memperbaiki penurunan massa dan kekuatan otot ${ }^{(16)}$.

Dalam melakukan aktivitas sehari-hari, kebugaran jasmani seperti kekuatan otot perut sangat berperan penting. Latihan aerobik merupakan parameter penting dari kebugaran fisik pada lansia. Kebugaran kardiovaskuler mempunyai kemampuan dalam meningkatkan kualitas hidup, menunda penurunan kognitif, dan memperpanjang kebugaran fungsional pada lansia dengan memastikan aspek fungsional dari individu tersebut ${ }^{(17)}$.

Brisk walking exercise sebagai salah satu bentuk latihan aerobik merupakan bentuk moderate exercise dengan menggunakan teknik jalan cepat selama 15-30 menit dengan kecepatan rata-rata $4-6 \mathrm{~km} / \mathrm{jam}$. Dari latihan brisk walking akan memberikan manfaat yaitu untuk meningkatkan kapasitas maksimal denyut jantung, merangsang kontraksi otot, pemecahan glikogen dan peningkatan oksigen jaringan. Selain itu juga dapat mengurangi pembentukan plak melalui peningkatan penggunaan lemak dan peningkatan penggunaan glukosa dengan latihan fisik ${ }^{(18)}$.

Brisk walking adalah latihan aerobik yang dinamis dan ritmis dengan menggunakan otot-otot besar sehingga memberikan manfaat beragam dan efek samping yang minimal ${ }^{(19)}$. Latihan aerobik menyebabkan bertambahnya pembuluh darah kapiler pada otot, sehingga memudahkan terjadinya difusi $\mathrm{O}_{2}$ didalam otot. Maka, mengakibatkan adanya kemampuan untuk mengangkut dan mempergunakan rata-rata $\mathrm{O}_{2}$ lebih besar dibanding yang tidak terlatih. Oleh karenanya dapat mengkonsumsi $\mathrm{O}_{2}$ lebih banyak perunit massa otot serta tahan lama dalam bekerja ${ }^{(20)}$.

Bila latihan dilakukan secara teratur dan disertai kebiasaan makan yang baik, berbagai sistem tubuh akan berubah secara positif. Otot-otot akan menjadi kuat dan dapat memikul kerja yang lebih besar dan akan memperlihatkan berkurangnya rasa lelah dengan bertambahnya setiap masa latihan (Chan, 2012). Motivasi yang tinggi juga akan mempengaruhi kemampuan untuk menghasilkan kekuatan yang maksimal. Pelatihan fisik dapat diterapkan sebagai cara non-farmakologis untuk meningkatkan kekuatan dan meningkatkan massa otot, yang mengakibatkan hilangnya massa tubuh. Motivasi untuk berlatih aktivitas fisik dapat meningkat disebabkan karena memahami tujuan, manfaat, dan aturan dalam latihan, tertarik dengan latihan yang dilakukan dan menikmatinya $^{(21)}$.

\section{KESIMPULAN}

Berdasarkan penelitian yang telah dilakukan dapat disimpulkan bahwa aerobic exercise yang dilakukan selama 3 minggu dapat memberikan pengaruh terhadap peningkatan upper body strength pada sampel calon jamah umrah di KBIH Al-Ikhlas.

\section{REFERENSI}

[1]. Agama, K. (2018). Pusat Data Kementrian Agama RI. Retrieved from Biro Hubungan Masyarakat Data dan Informasi website: https://data.kemenag.go.id/umrohdashboard/statis tik/jk

[2]. Arif Pristianto, Wijianto, F. R. (2018). Terapi Latihan Dasar. Surakarta: Oktober 2018.

[3]. Arwih, M. Z. (2018). Hubungan Kekuatan Otot Lengan Dengan Kemampuan Handstand Pada Olahraga Senam Lantai Mahasiswa Penjaskesrek Angkatan 2016 Kelas B Fkip Uho. Jurnal Ilmu Keolahragaan, $\quad 17(2), \quad 8$ https://doi.org/10.24114/jik.v17i2.12302

[4]. Chan, F. (2012). Strength Training (Latihan Kekuatan). Cerdas Sifa, 1(1), 1-8. Retrieved from https://onlinejournal.unja.ac.id/index.php/csp/article/view/703

[5]. Daa, P., La, S., Mcg, P., Jcb, M., Aq, R., \& Scc, F. (2019). Training Program of Aerobic and Strength Exercise on Physical and Metabolic Health of Young Female Undergraduate Students Abstract Subjects. Health Science Journal, 13(5), 1-10. https://doi.org/10.21767/1791809X.100676

[6]. Danang Ade Setiawan, A. S. (2014). Hubungan Indeks Massa Tubuh (Imt) Terhadap Kekuatan Otot Pada Lansia Di Panti Wredha Rindang Asih Iii Kecamatan Boja. JSSF (Journal of Sport Science and Fitness), 3(3), 30-35.

[7]. Guidelines for Exercise Testing and Prescription, Fourth Edition. (2013). In P. D. T. Linda S. Pescatello, Ross Arena, Deborah Riebe (Ed.), Medicine \& Science in Sports \& Exercise (ninth, Vol. 23). https://doi.org/10.1249/00005768199110000-00024

[8]. Keller, K., \& Engelhardt, M. (2013). Strength and muscle mass loss with aging process. Age and strength loss. Muscles, Ligaments and Tendons Journal, 3(4), 346-350. https://doi.org/10.11138/mltj/2013.3.4.346 
[9]. Lintin, G. B. R., \& Miranti. (2019). Hubungan Penurunan Kekuatan Otot Dan Massa Otot Dengan Proses Penuaan Pada Individu Lanjut Usia Yang Sehat Secara Fisik. Jurnal Kesehatan Tadulako, 5(1), 1-5.

[10]. Patel, H., Alkhawam, H., Madanieh, R., Shah, N., Kosmas, C. E., \& Vittorio, T. J. (2017). Aerobic vs anaerobic exercise training effects on the cardiovascular system. World Journal of Cardiology, $\quad 9(2), \quad$ 134-138. https://doi.org/10.4330/wjc.v9.i2.134

[11]. PERMENKES RI NOMOR 65. (2015). (1662), 154.

[12]. Prasetyo, Y., Doewes, M., Rahma, N., \& Anantanyu, S. (2017). Effects of Aerobic Exercise and Weight Training-Aerobic towards Physical Fitness of Elderly Hajj Candidates. International Journal on Advanced Science, Engineering and Information Technology, 7(1), 106. https://doi.org/10.18517/ijaseit.7.1.1446

[13]. Prativi, G. O., \& Soegiyanto, S. (2013). Pengaruh Aktivitas Olahraga Terhadap Kebugaran Jasmani. Journal of Sport Sciences and Fitness, 2(3), 32-36.

[14]. R., F. P., Wungouw, H. I. S., \& Marunduh, S. (2015). Pengaruh Latihan Beban Terhadap Kekuatan Otot Lansia. Jurnal E-Biomedik, 3(1). https://doi.org/10.35790/ebm.3.1.2015.8075

[16]. Sbardelotto, M. L., Costa, R. R., Malysz, K. A., Pedroso, G. S., Pereira, B. C., Sorato, H. R., ... Pinho, R. A. (2019). Improvement in muscular strength and aerobic capacities in elderly people occurs independently of physical training type or exercise model. Clinics, (7), 1-9. https://doi.org/10.6061/clinics/2019/e833

[17]. Suroto, Agus Mahendra, Taufiq Hidayah, dan A. K. (2018). Pendidikan Jasmani Olahraga dan Kesehatan. Jakarta: 2015.

[18]. Suryati, Ida, Dia Resti, Khairina, R. (2017). Kombinasi Stretching Active Dan Brisk Walking Terhadap Penurunan Tekanan Darah Klien Hipertensi. Jurnal Kesehatan Perintis, 4(2), 5560.

[19]. Trisnowiyanto, B. (2016). Pengaruh Abdominal Muscle Strengthening Dengan Metode Pilates. Fisioterapi Politeknik Kesehatan Kemenkes RI, Surakarta, VII(3), 440-444.

[20]. Umrah, D. J. H. dan. (2019). Pedoman Pendaftaran Jemaah Umrah.pdf (pp. 1-25). pp. $1-25$.

[21]. Wu, L. L., Wang, K. M., Liao, P. I., Kao, Y. H., \& Huang, Y. C. (2015). Effects of an 8-Week Outdoor Brisk Walking Program on Fatigue in
Hi-Tech Industry Employees. Workplace Health and Safety, 63(10), 436-445. https://doi.org/10.1177/2165079915589685

\section{Nama Penulis}

1. Agustiyawan, memperoleh Ahli Madya Fisioterapi pada tahun 2009 di Universitas Pembangunan Nasional Veteran Jakarta. Kemudian tahun 2011 memperoleh gelar Sarjana Sain Terapan Fisioterapi di STIKes Binawan Jakarta. Dan pada tahun 2015 telah menyelesaikan Program Pasca Sarjana Fisiologi Udayana. Saat ini sebagai Dosen Tetap Program Studi Fisioterapi Program Diploma Tiga Fakultas Ilmu Kesehatan Universitas Pembangunan Nasional Veteran Jakarta.

2. Dzakyah Amelya, Mahasiswa Program Studi Fisioterapi Program Diploma Tiga Fakultas Ilmu Kesehatan Universitas Pembangunan Nasional Veteran Jakarta Tahun Ajaran 2017. 